\title{
Contrasting macrobenthic activities differentially affect nematode density and diversity in a shallow subtidal marine sediment
}

\author{
Ulrike Braeckman $^{1, *}$, Carl Van Colen ${ }^{1}$, Karline Soetaert $^{2}$, Magda Vincx $^{1}$, \\ Jan Vanaverbeke ${ }^{1}$ \\ ${ }^{1}$ Department of Biology, Marine Biology Section, Ghent University, Krijgslaan 281/S8, 9000 Ghent, Belgium \\ ${ }^{2}$ Netherlands Institute of Ecology (NIOO-KNAW), Centre for Estuarine and Marine Ecology, PO Box 140, 4400 AC Yerseke, \\ The Netherlands
}

\begin{abstract}
By bioturbating and bio-irrigating the sea floor, macrobenthic organisms transport organic matter and oxygen from the surface to deeper layers, thereby extending the habitat suitable for smaller infauna. Next to these engineering activities, competition, disturbance and predation may also affect the spatial distribution of these smaller organisms. In a controlled laboratory experiment, we studied the effects of 3 functionally different macrobenthic species on the vertical distribution of nematodes. Abra alba, a suspension-deposit feeding bivalve reworking the sediment randomly, Lanice conchilega, a suspension-deposit feeding, tube-irrigating polychaete and Nephtys hombergii, a burrowing predatory polychaete, were added in single-species treatments to sediment from a coastal subtidal station in the Belgian part of the North Sea, sieved $(1 \mathrm{~mm})$ to remove macrofauna. After $14 \mathrm{~d}$, the control treatment without macrobenthos was found to be detrimental to nematode density and diversity, which points to the importance of macrobenthic engineering to sustain the smaller components of the food web. Nematode densities were highest at the sediment surface in all treatments, but subsurface density peaks were observed in A. alba (to $3 \mathrm{~cm}$ depth) and L. conchilega (to $7 \mathrm{~cm}$ depth) microcosms. In the $A$. alba treatment, the dominant non-selective deposit feeders and the epistrate feeders shifted downwards probably to avoid disturbance and exploitative competition by the bivalve siphons at the surface, while they might have benefited from the faecal pellets deposited in the subsurface. In the L. conchilega treatment, the several dominant species were redistributed over depth layers, indicating polychaete-mediated habitat extension from surface into depth. Nematode communities seemed hardly affected by the presence of $N$. hombergii. These results reveal that functionally contrasting macrobenthic engineering effects shape nematode communities in different ways, which may maintain the role of nematodes in ecosystem functioning. The present study therefore highlights the need for conservation of macrobenthic functional diversity.
\end{abstract}

KEY WORDS: Bioturbation · Macrobenthos · Ecosystem engineering $\cdot$ Nematodes · Vertical distribution · Diversity · Density

\section{INTRODUCTION}

One of the major goals of ecology is to understand the distribution of species, populations and communities. Disentangling the drivers of these distributions is challenging since a wide variety of biotic and abiotic factors are recognised as being important in shaping biological communities. Gaining insight into these complex mechanisms has now become more pressing than ever in light of changing habitats and increasing rates of species extinctions. A key pathway by which one organism can affect others is by physically changing its abiotic environment, so-called ecosystem engineering (Jones et al. 1994). For example, macrobenthic 
organisms that inhabit marine soft sediments alter the distribution of high-quality organic matter (Graf 1989, Levin et al. 1997), oxygen and toxic metabolites in the sediment (Kristensen \& Kostka 2005) through bioturbation and bio-irrigation activities (Aller 1988, Meysman et al. 2006) which, in turn, may influence the distribution of organisms that are too small to 'engineer' their own habitat, e.g. nematodes (Reise 1985) or bacteria (Mermillod-Blondin et al. 2004). The ecosystem-engineering concept is, however, controversial in that all organisms are affected by and change their abiotic environment to some extent (Reichman \& Seabloom 2002). Consequently, the utility of the concept requires explicit effects of the ecosystem engineer on other organisms that differ from direct biotic interactions (Hastings et al. 2007).

Nematode vertical distribution in marine soft sediments is tightly coupled to (1) the prevailing geochemical properties, such as hydrogen sulfide and oxygen concentrations (e.g. Platt 1977, Hendelberg \& Jensen 1993, Wetzel et al. 1995), and (2) food availability in the sediment (Franco et al. 2008a). These factors can be altered by bio-irrigation and bioturbation, not only by direct transport of solids and solutes, but also by stimulating biogeochemical processes along the burrow walls (Mermillod-Blondin et al. 2004). The sediments surrounding burrows likely support microbial communities that differ from those in the surficial sediments (Kristensen \& Kostka 2005) and may therefore diversify the menu for nematodes. Further, macrobenthic faecal casts give rise to high bacterial activity due to a greater concentration of fine particles, rich in organic carbon and nitrogen, than in the surrounding sediment (Reise 1985). In addition, macrobenthos may affect nematode communities positively, by the construction of physical structures (e.g. polychaete tubes) that provide shelter from predation (Zühlke et al. 1998), or negatively, by depleting their food resources (Olafsson et al. 1993), and by direct physical disturbance due to regular bioturbation (Austen \& Widdicombe 1998, Schratzberger $\&$ Warwick 1999).

Studies investigating the link between macro- and meiofauna (e.g. nematodes) are numerous (reviewed by Olafsson 2003, Dashfield et al. 2008, Bouchet et al. 2009) but evidence for the biogeochemical engineering effects of macrofauna on nematode distribution remains surprisingly scarce: the engineering mechanisms involved (i.e. altered environmental variables) are not always studied in detail (Olafsson et al. 1993, Austen et al. 1998, Austen \& Widdicombe 1998, Austen \& Thrush 2001) and therefore clear proof of interactions between macrobenthos, environmental variables and meiofauna are often lacking. Olafsson (2003) pointed out that enhancing the resolution in data collection, e.g. by taking the vertical distribution of the sediment into account and working at low(er) taxonomic levels, is crucial in determining macrofauna effects on nematodes. Moreover, the examination of whether macrofaunal species with a different functionality (in terms of bioturbation) differently affect nematode communities may help to identify the engineering mechanisms involved. Macrobenthic functional traits in terms of bioturbation are manifold and comprise (1) biodiffusers that rework the sediment at random, (2) gallery-diffusers that excavate and actively irrigate burrows, (3) upward-conveyors that remove sediment at depth in the substratum and expel it at the sediment-water interface, (4) downward-conveyors that cause 'active' transport of sediment through their gut from the sediment-water interface to their egestion depth and (5) regenerators that dig out sediment at depth and move it to the surface, where it is washed away and replaced by sediment from the surface (Gerino et al. 2003, Michaud et al. 2006). These differing traits have all been shown to make the biogeochemical sediment environment more heterogeneous (Mermillod-Blondin et al. 2004, Michaud et al. 2006, Braeckman et al. 2010) and thus potentially affect nematode vertical distribution.

The present work explores for the first time the nematode community response to functionally contrasting macrobenthic activities in shallow subtidal sediments, both on a detailed taxonomic level and with respect to their vertical distribution. We introduced 3 functionally different macrobenthic species in singlespecies treatments into microcosms containing (subtidal) sediment with the same natural nematode communities but devoid of the natural macrobenthic population. The 3 species are dominant representatives of the Abra alba-Kurtiella bidentata community in the Belgian part of the North Sea (Van Hoey et al. 2004). Both the bivalve A. alba and the polychaete Nephtys hombergii rework the sediment at random (i.e. they are biodiffusers), though the first species is a suspension-deposit feeder while the latter is a predator. The tube-irrigating, suspension-deposit feeding polychaete Lanice conchilega is sedentary and has limited impact on sediment turnover once the tubes are established. Its piston-pumping (Forster \& Graf 1995) stimulates microbial activity and enhances benthic mineralisation, whereas the biodiffusers A. alba and $N$. hombergii do not irrigate their burrows or feeding pits, resulting in a limited stimulation of benthic mineralisation rates (Braeckman et al. 2010).

We tested whether the presence of macrobenthos affects the vertical profile of environmental variables and nematodes, and whether different functional groups of macrobenthos have a contrasting effect on the vertical profile of environmental variables and nematodes. 


\section{MATERIALS AND METHODS}

Study site and sampling. The experimental set-up required sediment containing the natural vertical distribution of nematodes excluding abundant macrofauna. Therefore, sediment from a sandy coastal station off the coast of Oostende $\left(51^{\circ} 19.27^{\prime} \mathrm{N}, 2^{\circ} 52.09^{\prime} \mathrm{E}\right.$, $18 \mathrm{~m}$ depth, $9 \mathrm{~km}$ offshore) was collected with a Reineck boxcorer from the RV 'Zeeleeuw'. Sediment median grain size at the study site is $215 \pm 0.22 \mu \mathrm{m}$ with a mud fraction $(<63 \mu \mathrm{m})$ of $5.8 \pm 0.2 \%$. The macrobenthic community present belongs to the Abra albaKurtiella bidentata community (Van Hoey et al. 2004). The sediment was sliced into $0-1 \mathrm{~cm}, 1-3 \mathrm{~cm}, 3-5 \mathrm{~cm}$, 5-8 cm, 8-end $\mathrm{cm}$ sections, wet-sieved to remove macrofauna (>1 $\mathrm{mm}$ ) and brought to a temperaturecontrolled laboratory $\left(18^{\circ} \mathrm{C}\right) 7 \mathrm{~d}$ before the start of the experiment (Day -7 ). The naturally oxygenated $0-1 \mathrm{~cm}$ section was aerated overnight. During this sampling campaign, 3 cores of $3.6 \mathrm{~cm}$ internal diameter (i.d.), obtained from replicate deployments of the Reineck boxcorer, were sliced in $1 \mathrm{~cm}$ sections to serve as a field control (FC). Macrobenthos inhabiting these FC slices was retained on a $1 \mathrm{~mm}$ mesh. On Day -6 , the sediment column $(8 \mathrm{~cm})$ was reconstructed by stacking subsequent sediment horizons in cylindrical microcosms of $10 \mathrm{~cm}$ i.d. The microcosms were left to acclimatise in the dark for $4 \mathrm{~d}$ at $18^{\circ} \mathrm{C}$, covered with $20 \mathrm{~cm}$ of natural seawater of salinity 32 .

Lanice conchilega was collected in the intertidal area by means of metal frames (Rabaut 2009) and subsequently introduced into the microcosms within its tube as described in Ziegelmeier (1969) at a natural density of 637 ind. $\mathrm{m}^{-2}$ (corresponds to 5 animals introduced into each microcosm). To check the fitness of the animals, the fringed tube end was cut after introduction to the sediment. The next day, all animals had rebuilt a new crown of fringes. Abra alba and Nephtys hombergii were sampled from the subtidal with the RV 'Zeeleeuw' and introduced at a density of 764 ind. $\mathrm{m}^{-2}$ ( 7 animals introduced) and 382 ind. $\mathrm{m}^{-2}$ (3 animals introduced) respectively, which is within the ranges of their natural density (Degraer et al. 2006). $N$. hombergii and A. alba specimens that did not burrow within $30 \mathrm{~min}$ were replaced by more active individuals.

Experimental set-up and slicing. Twelve microcosms were attributed to 4 experimental treatments in triplicate: 3 experimental control (C) microcosms where reconstructed sediment was incubated without macrofauna; and 3 microcosms each with Abra alba, Lanice conchilega and Nephtys hombergii. Three additional reconstruction controls (RC) served as a procedural control for possible disturbance during and after microcosm reconstruction (homogenisation and compaction of the sediment). Microcosms were incubated at constant room temperature of $18^{\circ} \mathrm{C}$ for $14 \mathrm{~d}$. The overlying water in the microcosms was continuously aerated and replaced every $2 \mathrm{~d}$ to avoid accumulation of $\mathrm{NH}_{\mathrm{x}}$. The $3 \mathrm{RC}$ were sliced on Day 1 in $1 \mathrm{~cm}$ sections. On Day 14, all experimental microcosms were sliced in defined vertical sections as described above ('Study site and sampling'), but with higher resolution in the first $2 \mathrm{~cm}$ for closer inspection of nematode species response $(0-0.5,0.5-1,1-1.5$ and $1.5-2 \mathrm{~cm})$. The sediment from each slice was homogenised and subsamples were taken for nematode density and community analysis $(5 \mathrm{ml}$ in $0.5 \mathrm{~cm}$ slices and $10 \mathrm{ml}$ in $1 \mathrm{~cm}$ slices) and stored in a buffered $4 \%$ formalin solution. Meiofauna was extracted by centrifugation with Ludox (Heip et al. 1985). All nematodes were hand-picked, mounted onto slides and identified to genus or species level according to the pictorial key of Warwick et al. (1998). Sediment subsamples $(10 \mathrm{ml})$ were dried at $60^{\circ} \mathrm{C}$ and median grain size and silt content was determined with a Malvern Mastersizer using laser diffraction. Sediment subsamples for pigment analyses $(10 \mathrm{ml})$ were stored at $-80^{\circ} \mathrm{C}$ until analysis and sediment water content was calculated from the difference in weight between frozen and freeze-dried sediment. The freeze-dried sediment was extracted with $10 \mathrm{ml}$ of $90 \%$ acetone and pigment (chlorophyll a $\left[\begin{array}{ll}\mathrm{chl} & \mathrm{a}\end{array}\right]$, phaeophytin $a$ and phaeophytin $a$-like) concentrations in the supernatant were determined using HPLC (Gilson) analysis (Wright \& Jeffrey 1997).

Data analysis. A fully crossed 3-factor design was performed in PERMANOVA with random factor replicate (Rep) nested in the fixed factor treatment (TR), next to the fixed factor slice (Sl). The interaction term $\mathrm{TR} \times \mathrm{Sl}$ informs us about the difference in depth profiles of nematode uni- or multivariate measures or environmental variables among treatments. Since a PERMANOVA test can show significant differences between groups, but does not distinguish between a difference due to location (factor effects) or dispersion (variance), homogeneity of multivariate dispersion was tested with PERMDISP, using distances among centroids calculated both within Rep(TR) groups (averaged depths) and in TR $\times$ Sl (averaged replicates) groups. The PERMDISP test was never significant, indicating equally dispersed distances to centroids, hence a difference due to location ( $\mathrm{TR} \times \mathrm{Sl}$ interaction, hence 'profile'). In case of significant TR $\times$ Sl interactions, pairwise tests of TR within TR $\times \mathrm{Sl}$ were performed to investigate in which slice the treatments differed or vice versa. With only significant single-factor effects, pairwise tests within each factor were carried out. Because of the restricted number of possible permutations in pairwise tests, $p$-values were obtained from Monte Carlo samplings (Anderson \& Robinson 
2003). The 3-factor design was used for both multivariate and univariate analyses since PERMANOVA allows us to perform univariate ANOVAs with p-values obtained by permutation (Anderson \& Millar 2004), thus avoiding the assumption of normality. A Euclidean distance and Bray-Curtis based resemblance matrix was used for univariate and multivariate measures. The TR effect on the vertical structure of the nematode community was tested on (1) standardised (to account for differences in total nematode abundances among treatments) and square root-transformed data (to reduce the importance of dominant species) and on (2) raw data to take differences in species/genus abundance into account.

First, the difference between $\mathrm{FC}, \mathrm{RC}$ and $\mathrm{C}$ profiles in terms of nematode density and community composition was tested. Further analyses considered experimental treatments only. The effect of macrobenthos on the totals and depth profiles of densities, diversity indices (species richness $[S]$, evenness $\left[J^{\prime}\right]$, and Hill's indices $N_{1}$ and $N_{\infty}$ ) and depth profiles of environmental variables was analysed. Sample sizes varied between levels of depth $(5 \mathrm{ml}$ for $0.5 \mathrm{~cm}$ slices, $10 \mathrm{ml}$ for $1.0 \mathrm{~cm}$ slices). As samples vary proportionally, a non-linear relationship between sample volume and number of species cannot be excluded. Thus for all statistical analyses on nematode community structure and diversity indices that include depth horizons through the whole core $(0$ to $8 \mathrm{~cm}), 0.5 \mathrm{~cm}$ slice samples were combined into $1.0 \mathrm{~cm}$ slices to give comparable sample sizes, and separate analyses were run on the upper $2 \mathrm{~cm}$ samples at $0.5 \mathrm{~cm}$ discrimination.

Within the multivariate analyses, a SIMPER analysis was selectively carried out on the slices that differed significantly among treatments in nematode community composition. A second-stage MDS plot with additional ANOSIM visualises the correlation between the vertical profiles of the nematode community composition. DISTLM (DISTance Based Linear Models) is a routine for analysing and modeling the relationship between a multivariate data cloud and one or more predictor variables. This analysis was carried out to identify the environmental parameter $(1 \mathrm{~cm}$ scale) with the greatest influence on the variance distribution of the nematode community composition. After elimination of highly correlated (i.e. $|r|>0.8$ ) variables (i.e. $\%$ silt with median grain size), this analysis was performed on the normalised variables chl $a$, phaeophytin $a$, phaeophytin a-like pigment, \%silt and water content using a global BEST selection procedure with Bayesian Information Correction (BIC). A generalised linear model (GLM) calculated the amount of variation in the nematode univariate measures (Poisson distribution was assumed) explained by combinations of environmental variables. If the residual variance exceeded the degrees of freedom, the data were 'overdispersed', and one of the assumptions of GLMs was violated. In this case, a compensation of the significance values was included in the models (Breslow 1984). The GLM accompanying adjusted $\mathrm{D}^{2}$ is reported, which is a measure (equivalent to adjusted $\mathrm{R}^{2}$ in least squares models) that resembles the fit of the model and increases with an increasing number of observations (n) or a decreasing number of parameters in the model (Guisan \& Zimmermann 2000).

All analyses were performed within PRIMER v6 with PERMANOVA add-on software (Clarke \& Gorley 2006, Anderson et al. 2008). Exceptions were the 1 -way ANOVAs on the difference in total nematode densities and diversity indices among treatments with additional Tukey HSD post hoc tests and the GLM carried out in R 2.6.0 software (www.r-project.org). Results are expressed as mean $\pm \mathrm{SE}$ of triplicates.

\section{RESULTS}

\section{Procedural controls}

Macrobenthos resident in the FC was very scarce, consisting of $1.3 \pm 0.4$ Nephtys sp. juveniles $10 \mathrm{~cm}^{-2}$ and $0.3 \pm 0.4$ Aonides sp. juveniles $10 \mathrm{~cm}^{-2}$ concentrated in the upper $2 \mathrm{~cm}$.

The total nematode density in the $\mathrm{FC}, \mathrm{RC}$ and $\mathrm{C}$ did not differ significantly (1-way ANOVA: $F_{2,6}=2.71, \mathrm{p}=$ $0.15)$. The vertical profiles of the nematode densities, however, were distinct (Fig. 1; Table S1 in the Supplement at www.int-res.com/articles/suppl/m422p179_ supp.pdf). Nematode densities in the FC increased gradually to a depth of $3 \mathrm{~cm}$, below which they decreased again with depth, while in both $\mathrm{C}$ and $\mathrm{RC}$ this gradual pattern was replaced by a sharp decline in nematode densities below $1 \mathrm{~cm}$. Significant differences between $\mathrm{C}$ and $\mathrm{RC}$ were observed in the deepest sediment layers: the RC had a significantly higher nematode density at depth than the FC and C. Also in terms of nematode community structure, in the FC the vertical structure was distinct from the $C$, but mainly in terms of abundance of dominant species (as detected by the higher pseudo- $F$ value in the PERMANOVA analysis on raw data vs. standardised and square roottransformed data) (Table S2 in the supplement). The differences between FC and RC must be linked to manipulations during reconstruction, i.e. sieving and homogenising, and sediment compaction due to removal of particles and fauna $>1 \mathrm{~mm}$. In contrast, apart from a lower nematode density in the deepest layer in $\mathrm{C}$ probably due to anoxia-related mortality, nematode communities in $\mathrm{C}$ did not differ from those in RC. Thus, maintaining the microcosms in experimental 
(a) Field control

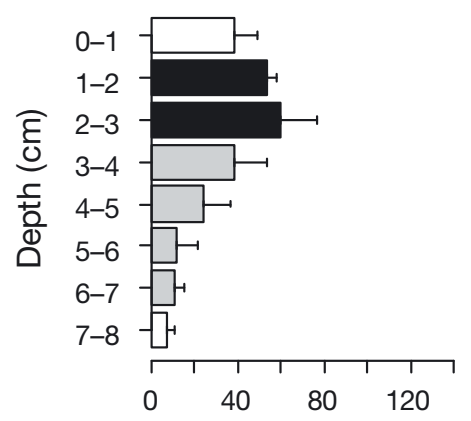

(b) Reconstruction control

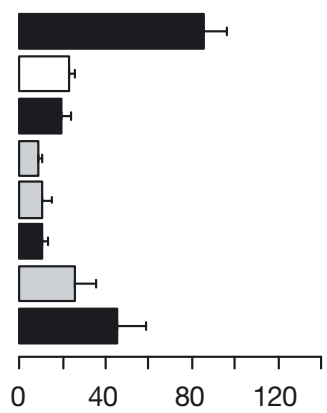

(c) Experimental control

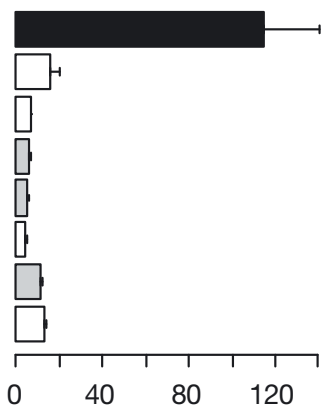

Nematode density (ind. $10 \mathrm{~cm}^{-2}$ )

Fig. 1. Nematode density profiles in field (a), reconstruction (b) and experimental (c) controls. The higher (black bar) and lower (white bar) nematode density of each pair according to pairwise tests of TR within TR $\times \mathrm{Sl}$ and slices not significantly different from other slices (grey bar) are indicated. Error bars indicate SE

Table 1. PERMANOVA results for environmental variables, general univariate community variables and the 5 most abundant nematode species. N: nematode abundance; $S$ : species richness; $J^{\prime}$ : evenness; ns: not significant. P-values obtained by permutation

\begin{tabular}{|c|c|c|c|c|c|c|c|c|c|c|c|c|}
\hline \multirow[t]{2}{*}{ Variable } & \multicolumn{4}{|c|}{ - Treatment- } & \multirow[b]{2}{*}{$\mathrm{df}$} & \multirow[b]{2}{*}{ MS } & \multirow{2}{*}{$\begin{array}{l}\text { Slice }- \\
\text { Pseudo- } \\
\quad F\end{array}$} & \multirow[b]{2}{*}{$\mathrm{p}$} & \multirow{2}{*}{$\mathrm{df}$} & \multicolumn{3}{|c|}{-Treatment $\times$ Slice } \\
\hline & df & MS P & $\begin{array}{l}\text { Pseudo- } \\
\text { F }\end{array}$ & p & & & & & & MS & $\begin{array}{c}\text { Pseudo- } \\
\text { F }\end{array}$ & p \\
\hline Median grain size & 3 & 29.75 & 2.83 & ns & 9 & 31.04 & 7.97 & $<0.001$ & 27 & 6.18 & 1.59 & ns \\
\hline$\%$ Silt & 3 & 29.30 & 1.38 & $\mathrm{~ns}$ & 9 & 35.37 & 9.37 & 0.001 & 27 & 6.00 & 1.59 & ns \\
\hline Water content & 3 & 1.28 & 2.37 & $\mathrm{~ns}$ & 9 & 79.382 & 8.82 & $<0.001$ & 27 & 3.17 & 2.18 & 0.005 \\
\hline Chlorophyll a & 3 & 59.78 & 1.75 & ns & 9 & 95.69 & 8.56 & $<0.001$ & 27 & 18.15 & 1.62 & 0.001 \\
\hline Phaeophytin a & 3 & 0.00 & 1.02 & ns & 9 & 0.01 & 20.53 & $<0.001$ & 27 & 0.00 & 1.94 & 0.014 \\
\hline Phaeophytin a-like pigment & 3 & 0.02 & 1.28 & ns & 9 & 0.01 & 13.26 & 0.001 & 27 & 0.00 & 1.21 & ns \\
\hline $\mathrm{N}$ & 3 & 1133.40 & 4.10 & ns & 9 & 19825 & 54.54 & $<0.001$ & 27 & 1566.70 & 4.31 & $<0.001$ \\
\hline$S$ (whole core, cm scale) & 3 & 92.40 & 13.44 & 0.003 & 7 & 464.92 & 49.28 & $<0.001$ & 21 & 19.43 & 2.06 & 0.017 \\
\hline$S$ (upper $2 \mathrm{~cm}, 0.5 \mathrm{~cm}$ scale) & 3 & 33.5 & 8.46 & 0.009 & 3 & 211.33 & 16.63 & $<0.001$ & 9 & 34.72 & 2.73 & 0.020 \\
\hline$J^{\prime}$ (whole core, cm scale) & 3 & 0.09 & 1.31 & ns & 7 & 0.04 & 1.23 & ns & 21 & 0.02 & 0.69 & ns \\
\hline Hill's $N_{1}$ (whole core, cm scale) & 3 & 37.98 & 23.35 & 0.006 & 7 & 81.38 & 18.50 & $<0.001$ & 21 & 9.66 & 2.20 & 0.011 \\
\hline$N_{1}$ (upper $2 \mathrm{~cm}, 0.5 \mathrm{~cm}$ scale) & 3 & 22.04 & 17.67 & $<0.001$ & 3 & 19.406 & 4.19 & 0.016 & 9 & 10.98 & 2.37 & 0.042 \\
\hline Hill's $N_{\infty}$ (whole core, cm scale) & 3 & 1.84 & 4.32 & ns & 7 & 2.67 & 3.02 & 0.009 & 21 & 1.45 & 1.64 & ns \\
\hline$N_{\infty}$ (upper $2 \mathrm{~cm}, 0.5 \mathrm{~cm}$ scale) & 3 & 4.52 & 15.66 & 0.005 & 3 & 1.92 & 1.90 & ns & 9 & 1.44 & 1.43 & ns \\
\hline Richtersia inaequalis & 3 & 87.37 & 1.47 & ns & 9 & 2343.70 & 36.83 & $<0.001$ & 27 & 139.58 & 2.19 & 0.006 \\
\hline Sabatieria celtica & 3 & 53.54 & 3.29 & ns & 9 & 85.27 & 5.56 & $<0.001$ & 27 & 30.77 & 2.01 & 0.013 \\
\hline Sabatieria punctata & 3 & 18.41 & 0.89 & ns & 9 & 13.94 & 1.53 & ns & 27 & 11.66 & 1.28 & ns \\
\hline Dichromadora cucullata & 3 & 9.43 & 4.09 & ns & 9 & 462.45 & 74.62 & $<0.001$ & 27 & 40.13 & 6.47 & $<0.001$ \\
\hline Microlaimus conothelis & 3 & 20.30 & 0.80 & ns & 9 & 58.78 & 4.72 & 0.001 & 27 & 32.35 & 2.60 & 0.004 \\
\hline
\end{tabular}

conditions did not introduce large differences into the systems, and the patterns observed among experimental treatments can be linked to the effect of macrobenthic presence.

\section{Experimental treatments}

\section{Survival of added macrobenthos}

All added macrobenthos except 1 Abra alba individual were recovered live on slicing. A. alba individuals were found between 1.5 and $7 \mathrm{~cm}$ depth and mainly (77\%) between 2 and $4 \mathrm{~cm}$ depth. Nephtys hombergii resided between 1 and $6 \mathrm{~cm}$ depth, with $76 \%$ in the 2 to $5 \mathrm{~cm}$ layer. Lanice conchilega tubes extended to the very bottom of the microcosms $(8 \mathrm{~cm})$.

\section{Environmental variables}

The macrobenthic functional groups did not affect the depth profiles of sediment median grain size and silt content (i.e. no interaction effect of $\mathrm{TR} \times \mathrm{Sl}$ ) and there was only a significant 'Slice' effect (Table 1): sediment median grain size was smaller and silt content higher in the top centimetre in all experimental treatments. The water content of the sediment was sig- 

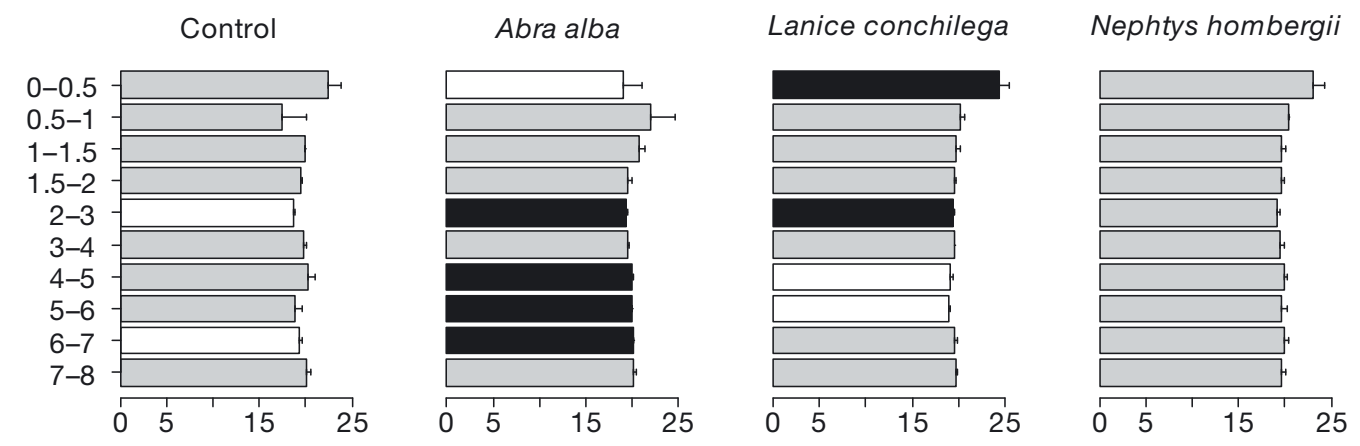

(a) Water content (\%) of the sediment
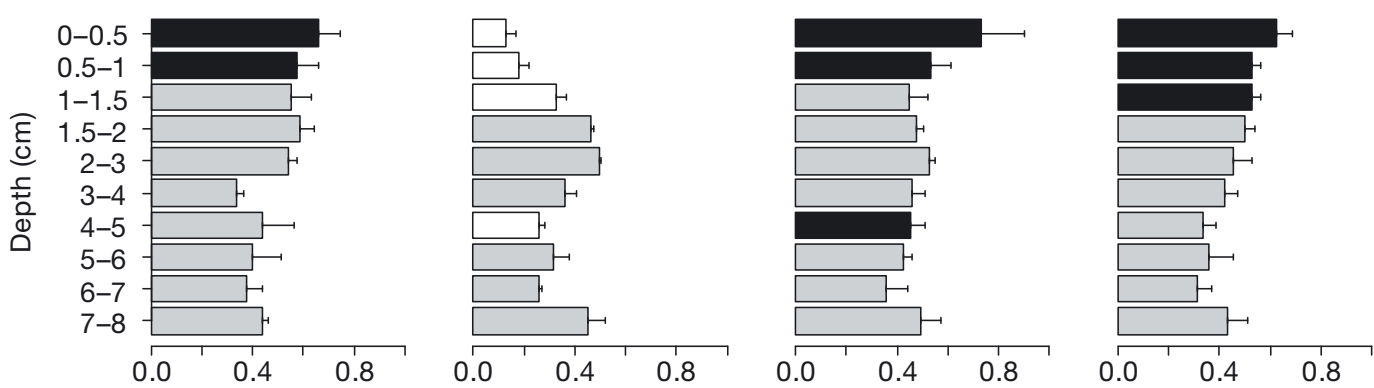

(b) Chlorophyll a ( $\mu \mathrm{gg}$ g sediment $\left.^{-1}\right)$
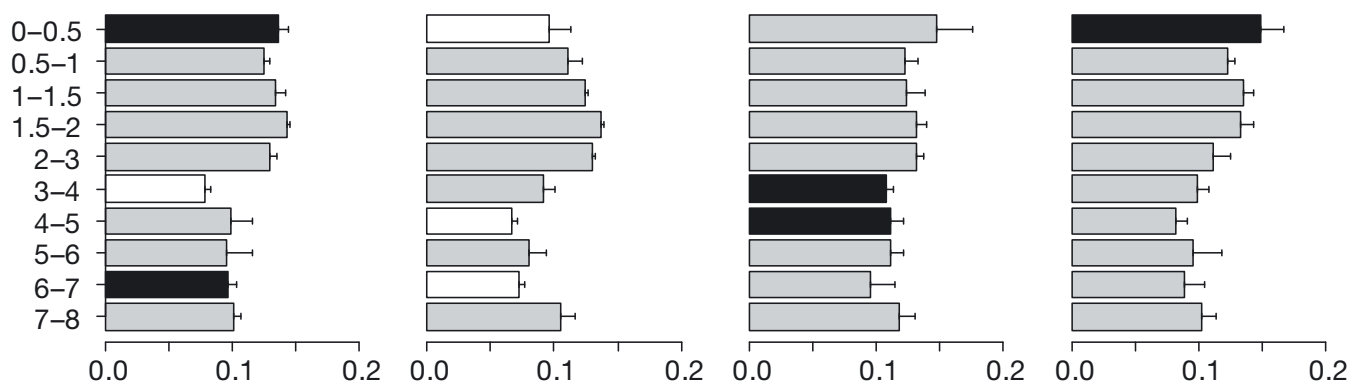

(c) Phaeophytin a ( $\mu \mathrm{gg}$ g sediment $\left.{ }^{-1}\right)$

Fig. 2. (a) Water content, (b) chlorophyll a and (c) phaeophytin a profiles in control, Abra alba, Lanice conchilega and Nephtys hombergii treatments (from left to right). Grey shades as in Fig. 1. Error bars indicate SE

nificantly altered by the macrobenthic treatments (Table 1, Fig. 2) and was significantly enhanced in the Lanice conchilega treatment in the upper $0.5 \mathrm{~cm}$ (compared to the Abra alba treatment) and in the $2-3 \mathrm{~cm}$ layer (compared to control). Water content in the $A$. alba treatment was higher in the $2-3 \mathrm{~cm}$ and $6-7 \mathrm{~cm}$ layers (compared to control) and the 4-6 cm layer (compared to L. conchilega) (Table S3 in the supplement). Chl a profiles were also significantly structured by the macrobenthic treatments (Table 1, Fig. 2): the chl a content of the $A$. alba treatments was depleted in the upper $1.5 \mathrm{~cm}$, and also the $4-5 \mathrm{~cm}$ layer of this treatment had a lower chl a content than the same slice in the L. conchilega treatment (Table S3). The profile of the chl a degradation products differed among treatments for phaeophytin $a$, but not for phaeophytin $a$ like pigment (Table 1). Phaeophytin a content followed a similar pattern to chl $a$, although less pronounced, being significantly lower in the surface layer of the $A$. alba treatment.

\section{Nematode density and diversity}

The average total number of nematodes per treatment (over the entire microcosm of $8 \mathrm{~cm}$ depth) was $233 \pm$ 18 ind. $10 \mathrm{~cm}^{-2}$. Nematode densities differed among treatments (Table S4 in the supplement) and were significantly higher in Lanice conchilega microcosms than in control microcosms (Tukey HSD post hoc: $p=0.033$ ). As the proportion of juveniles was equal in all treatments, this difference should be attributed to mortality in the controls. The macrobenthic species belonging to 3 different functional groups had contrasting structuring effects 

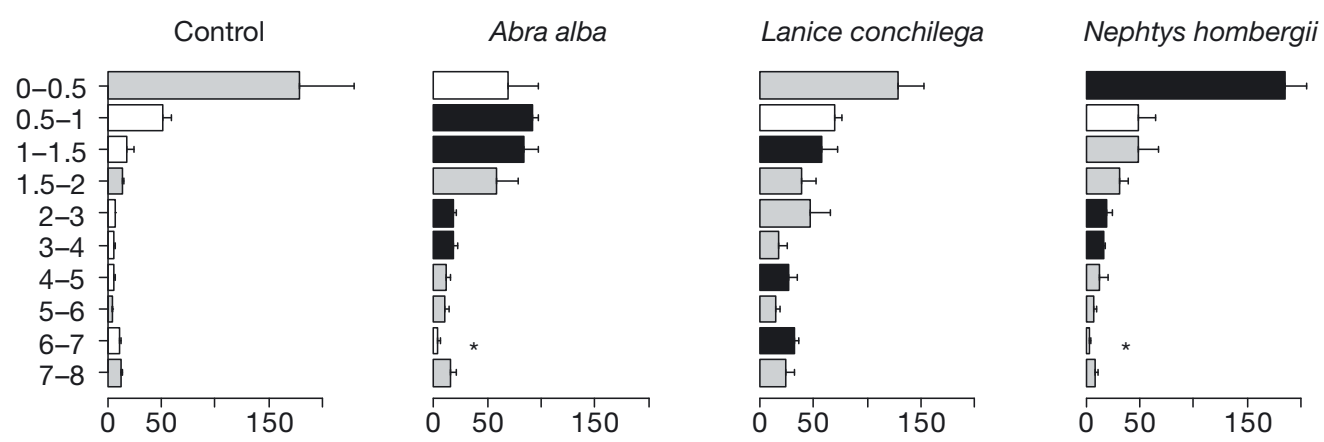

(a) Nematode density (ind. $10 \mathrm{~cm}^{-2}$ )
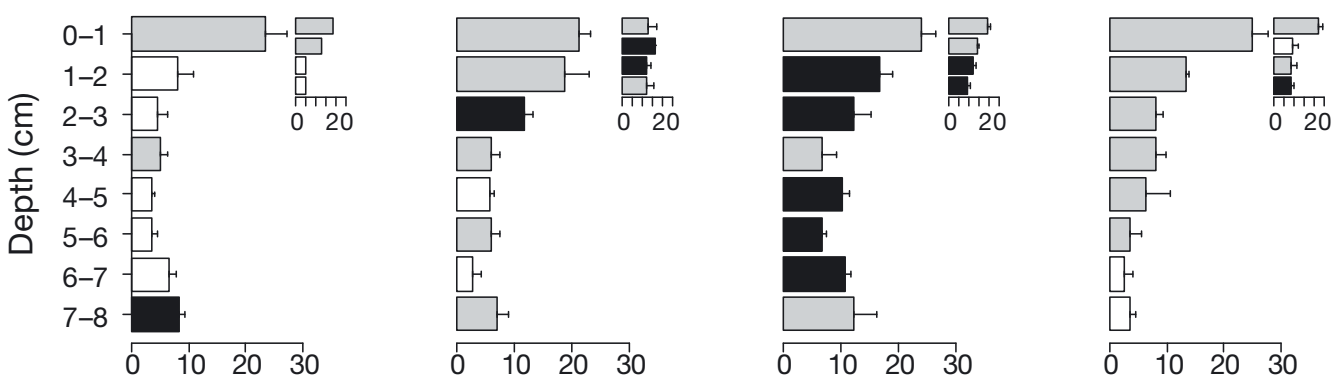

(b) Species richness (species $10 \mathrm{~cm}^{-2}$ )
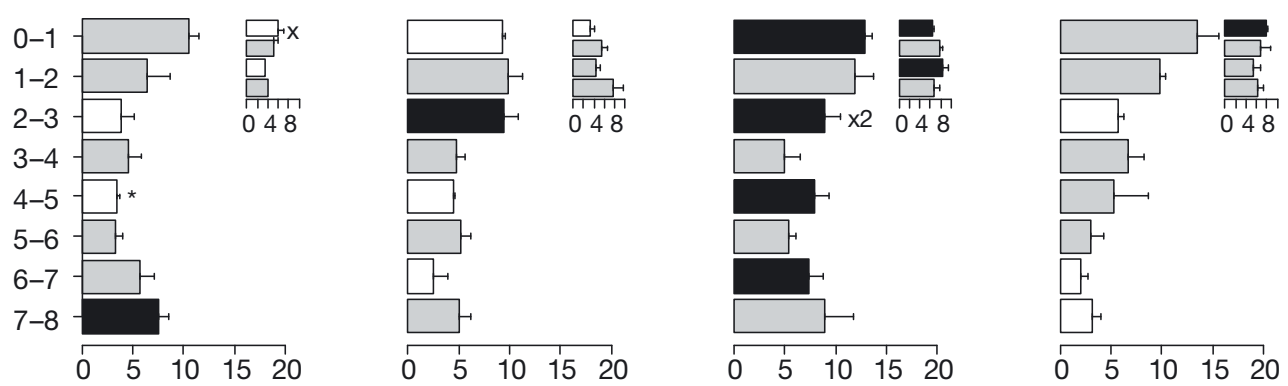

(c) Hill's diversity index $N_{1}$

Fig. 3. Nematode (a) density and (b,c) diversity (b: species richness; c: Hill's diversity index $N_{1}$ ) profiles in control, Abra alba, Lanice conchilega and Nephtys hombergii treatments (from left to right). Main graphs indicate analyses on whole core (cm scale); inset graphs show analyses on the upper $2 \mathrm{~cm}\left(0.5 \mathrm{~cm}\right.$ scale). ${ }^{*}$ Significantly lowest values. $\mathrm{x}$ : $N_{1}$ of the control $0-0.5 \mathrm{~cm}$ slice was only lower than the $0-0.5 \mathrm{~cm}$ slice of $N$. hombergii. x2: $N_{1}$ of the L. conchilega $2-3 \mathrm{~cm}$ layer was only higher than $N_{1}$ of the control 2-3 cm layer. Grey shades as in Fig. 1. Error bars indicate SE

on the vertical distribution of the nematodes (Table 1, Fig. 3). Whereas nematode densities declined rapidly below $0.5 \mathrm{~cm}$ in the control treatment, significant subsurface peaks were observed (Fig. 3, Table S5 in the supplement) in Abra alba (0.5 to $1.5 \mathrm{~cm}, 2$ to $4 \mathrm{~cm}$ ) and Lanice conchilega ( 1 to $1.5 \mathrm{~cm}, 4$ to $5 \mathrm{~cm}, 6$ to $7 \mathrm{~cm}$ ) treatments. In the Nephtys hombergii microcosms, nematodes were likewise found somewhat deeper than in the control microcosms ( 2 to $3 \mathrm{~cm}, 3$ to $4 \mathrm{~cm}, 6$ to $7 \mathrm{~cm}$ ). Nematode abundance in the upper $0.5 \mathrm{~cm}$ in the $A$. alba treatments was significantly lower than in the $N$. hombergii treatments, whereas in the $0.5-1 \mathrm{~cm}$ layer it was significantly higher than in all other macrobenthic treatments.

A total of 80 nematode species was identified, with Richtersia inaequalis, Sabatieria celtica, S. punctata,
Microlaimus conothelis and Dichromadora cucullata the 5 most abundant. Total species richness $(S)$ and evenness $\left(J^{\prime}\right)$ over the entire depth range did not differ among treatments, but Hill's indices $N_{1}$ and $N_{\infty}$ were different (Table S4) and $N_{\infty}$ was significantly higher in the Nephtys hombergii treatment than in the Abra alba (Tukey post hoc: $\mathrm{p}=0.02$ ) and control (Tukey post hoc: $\mathrm{p}=0.04$ ) treatments. This indicates that the commonest species (i.e. $R$. inaequalis) was less dominant in the $N$. hombergii treatment. For $N_{1}$, no significant pairwise tests were found. Evenness $\left(J^{\prime}\right)$ depth profiles were similar in all treatments, whereas profiles of species richness $(S)$ and Hill's diversity index $N_{1}$ differed significantly among treatments (Table 1, Fig. 3). Species richness $(S)$ was enhanced in the $0.5-1.5$ and $2-3 \mathrm{~cm}$ 


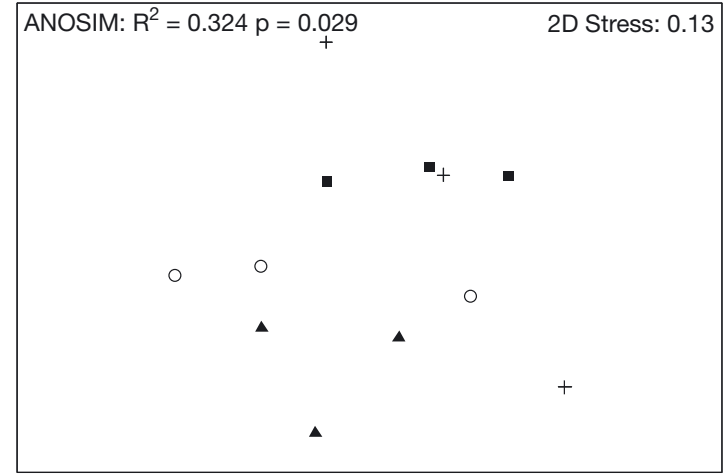

Fig. 4. Second-stage MDS plot of Spearman rank correlations between nematode community profiles on whole core $(\mathrm{cm}$

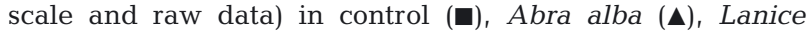
conchilega (+) and Nephtys hombergii (O) treatments

layer of the A. alba treatment and in several depth layers between 1 and $7 \mathrm{~cm}$ depth in the Lanice conchilega treatment (Table S5). Similarly, Hill's diversity index $N_{1}$ was enhanced in several depth layers of the $L$. conchilega treatment (Fig. 3, Table S5) and in the $2-3 \mathrm{~cm}$ layer of the A. alba treatment.

\section{Nematode community}

The vertical structure of the nematode community composition in the whole core was different among experimental treatments when analysed with raw data as well as with standardised, square root-transformed data (Table S6 in the supplement). Pairwise tests on raw data (whole core) showed a significant difference among treatments in nematode community composition in the 3-4 cm horizon between control and Abra alba treatment $(t=1.94$; Monte-Carlo $\mathrm{p}=0.042)$. SIMPER analyses (Table S7 in the supplement) indicated that this difference could be accounted for by higher densities of Sabatieria punctata and Spirinia spp. at that depth in the A. alba treatment compared to control, while Richtersia inaequalis was completely absent in that horizon of the A. alba treatment. The analysis on the upper $2 \mathrm{~cm}$ only showed differences in vertical nematode community structure when analysed with raw data (Table S6). Pairwise tests on these raw data indicated a significant difference among treatments in community composition in the $0.5-1 \mathrm{~cm}$ horizon between the A. alba and Nephtys hombergii treatment $(t=$ 1.80; Monte-Carlo $\mathrm{p}=0.049$ ). SIMPER analyses (Table $\mathrm{S7}$ ) showed that $R$. inae- qualis, Dichromadora cucullata and to a lesser extent Microlaimus conothelis occurred in higher densities in the A. alba treatment of this horizon, while Sabatieria celtica and Sabatieria punctata were more dominant in the $N$. hombergii treatment of this horizon. Only the ANOSIM on the whole core based on raw data showed significantly different nematode community profiles among treatments (visualised in the second-stage MDS plot in Fig. 4), which implies that the major nematode community changes take place over the entire depth range and are mainly a result of the response of the dominant species.

\section{Dominant species}

The vertical distribution of Richtersia inaequalis differed significantly among treatments (Table 1, Fig. 5a). The difference was mainly due to the significantly higher densities in the $0.5-2 \mathrm{~cm}$ horizons of the Abra alba treatment. Whereas the profiles of Sabatieria punctata were unaffected by the macrobenthic treatment, the profiles of its congener $S$. celtica (Table 1, Fig. 5b) differed significantly among treatments. Microlaimus conothelis (Fig. 5c) and Dichromadora cucullata (Fig. 5d) profiles also differed among macrobenthic treatments (Table 1) mainly due to higher densities in deeper layers of the Lanice conchilega (S. celtica, M. conothelis) and A. alba treatments $(S$. celtica), and differences in the surface layers (D. cucullata, M. conothelis).

\section{Correlation between environmental variables and nematode distribution}

The DISTLM routine with global BEST analysis and BIC correction revealed that the combination of phaeophytin a $(9.15 \%$ of the variation explained) and water

Table 2. Results of regression model, corrected for overdispersion, between nematode univariate measures and environmental variables that are significantly affected by macrobenthic presence. $N$ : nematode abundance; $S$ : species richness; $N_{1}$ : Hill's diversity index; ns: not significant

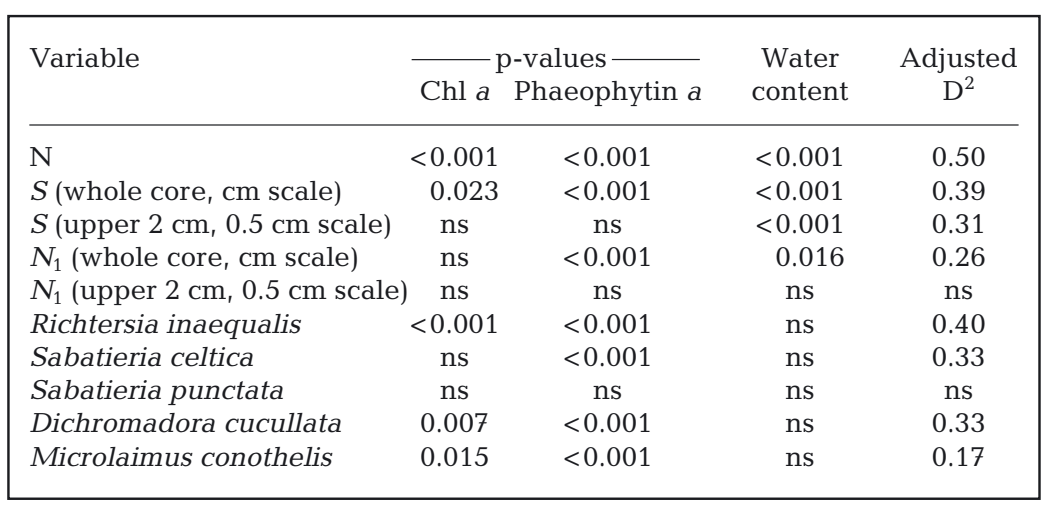




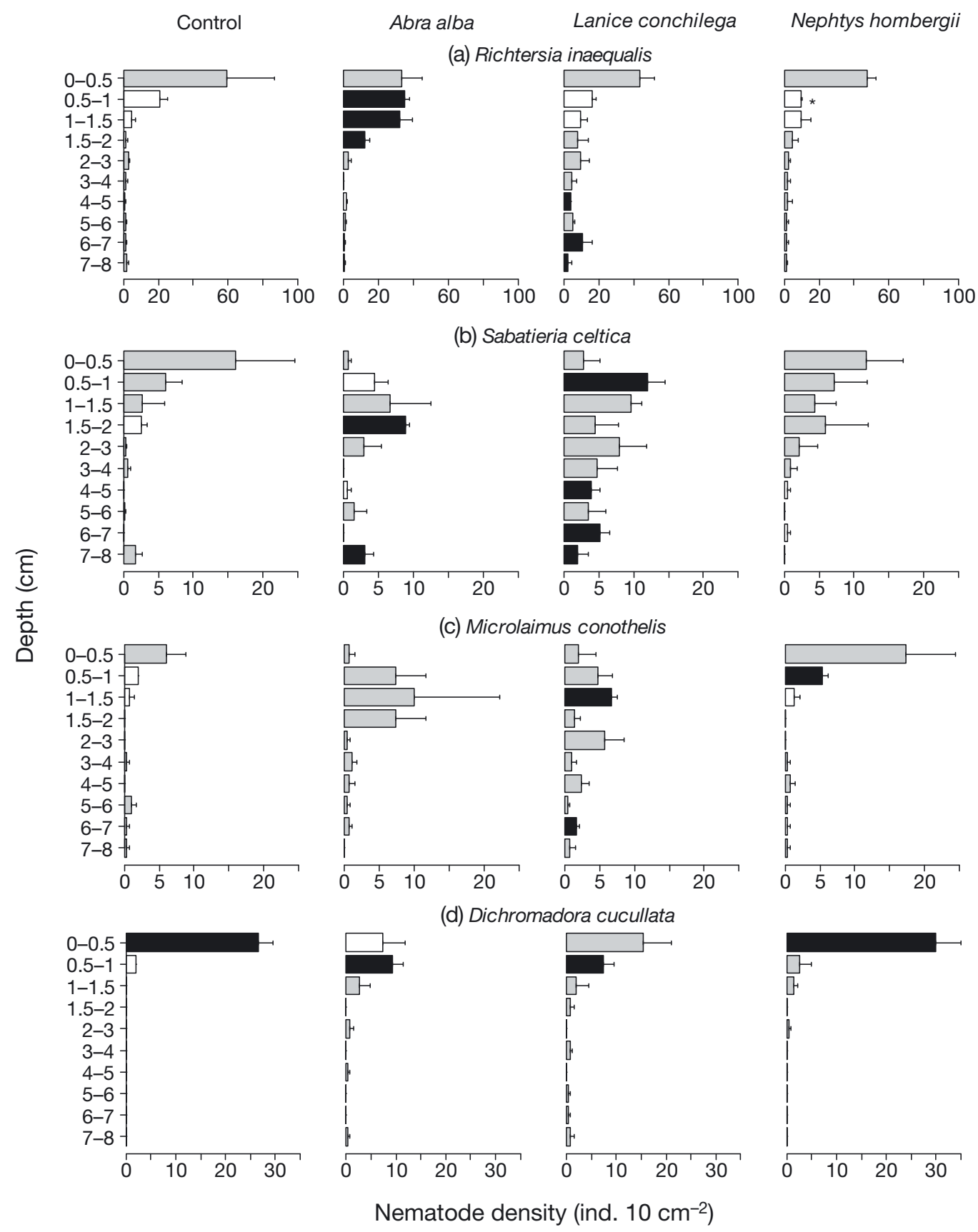

Fig. 5. (a) Richtersia inaequalis, (b) Sabatieria celtica, (c) Microlaimus conothelis and (d) Dichromadora cucullata density profiles in control, Abra alba, Lanice conchilega and Nephtys hombergii treatments (from left to right). ${ }^{*}$ Significantly lowest values. Grey shades as in Fig. 1. Error bars indicate SE

content $(6.87 \%$ of the variation explained) explains the structure in the multivariate data set (whole core, raw data) the best. However, this correlation is quite low $\left(\mathrm{R}^{2}=0.138\right)$. In contrast, the GLM model using combinations of environmental variables explains the variation in the univariate measures of the nematode community by between 17 and $50 \%$, except for $N_{1}(2 \mathrm{~cm})$ and Sabatieria punctata (Table 2).

\section{DISCUSSION}

The present laboratory study demonstrates a significant effect of macrobenthos on the vertical distribution of nematodes, in terms of density, diversity and community composition, corroborating earlier observations on the structuring effect of macrobenthos on nematode communities (Olafsson 2003, Pinto et al. 2006, Dash- 
field et al. 2008). However, by identifying nematodes to the lowest taxonomic level and resolving their vertical profile, we revealed that (1) these nematode community responses are due to increased densities of the dominant non-selective deposit-feeding (Richtersia inaequalis and Sabatieria celtica) and epistrate-feeding (Dichromadora cucullata and Microlaimus conothelis) species at certain depths, and that (2) the type of response depends on the macrobenthic functional traits (in terms of bioturbation and bio-irrigation). Furthermore, the densities of the nematode species most responsible for the changes in community structure were related to the environmental variables altered by the resident macrofauna (i.e. water content and photopigments), suggesting ecosystem-engineering effects of macrofauna on nematodes. Yet, these environmental variables did not fully explain the vertical structure of the nematode community composition (cf. the low $\mathrm{R}^{2}$ value in the DISTLM analysis). (1) This may point at missing measurements of important structuring factors such as oxygen penetration depth (Steyaert et al. 2005). (2) It may indicate a uniform response of the nematode species to the altered environmental variables, as reflected in the higher correlation with the univariate measures nematode density and diversity. (3) It demonstrates that apart from engineering the environmental variables, biotic interactions might play a role in the vertical structure of nematode community composition.

Nematodes experienced higher mortality in the control sediment without macrofauna, and those that survived concentrated in the upper centimetre of the sediment, apparently because bioturbation and bioirrigation were lacking, which reduced subsurface oxygen concentrations and increased concentrations of toxic metabolites (Steyaert et al. 2003, 2005, 2007, Franco et al. 2008b). In addition, nematode diversity in these controls was impoverished in several depth layers compared to the sediments with macrofauna present. Widdicombe et al. (2003) pointed out that bioturbation is essential for species diversity by producing heterogeneity or complexity within the sediment. Importantly, the significantly different treatment effects suggest differing underlying mechanisms (as hypothesised in the following subsections) for the observed nematode community responses depending on macrofaunal functional identity.

\section{Abra alba: exploitative competition and disturbance at the surface vs. faecal pellets in subsurface}

Nematode density was significantly lower in the surface layer reworked by Abra alba. Nematodes seemed to have migrated downwards, resulting in higher den- sities between 0.5 and $4 \mathrm{~cm}$ sediment depth, which was particularly clear for the dominant species Richtersia inaequalis, Dichromadora cucullata and Sabatieria celtica, as shown by the different community profile of the $A$. alba treatment based on raw data (whole core, response of dominant species not weighed down; Fig. 4). Despite the substantial bioturbation activity of A. alba (Braeckman et al. 2010), its activity is probably limited to sediment reworking and does not consist of deep organic-matter burial (Graf 1989, Levin et al. 1997). During the present experiment, most of the labile organic matter was consumed by $A$. alba (emptied chl a profile in Fig. 2) and little to none was left for subsurface transport. Hence, the downward migration of nematodes cannot be linked to transport of food from the surface to depth. It therefore presumably relates to the depletion of food resources (diatoms) of the nonselective deposit- and epistrate-feeders sensu Wieser (1953) due to deposit-feeding activities of $A$. alba at the surface. In addition, the sediment-sucking siphons may have caused a substantial physical disturbance in the first $0.5 \mathrm{~cm}$, thereby chasing the nematodes downwards. Direct predation seems unlikely as the size of particles taken up by $A$. alba siphons is smaller than the size of nematodes (Austen et al. 1998). The enhanced water content and thus related interstitial space around the bivalve might have facilitated the mobility of nematodes (McIntyre 1969). Furthermore, the downward shift of $R$. inaequalis and $D$. cucullata, both known to be intolerant to oxygen stress (Steyaert et al. 2007, Franco et al. 2008b), suggests the presence of small oxygen pulses into the sediment in close vicinity of the bivalve, likely facilitating the deeper survival of these species (Bouchet et al. 2009). Reise (1983) related an increased turbellarian density in close vicinity of the deposit-feeding bivalve Macoma balthica to the subsurface creation of micro-oxic zones and nutrientstimulated micro-organism growth. Similarly, in the present experiment, the downward shift of the nematodes was concentrated between 0.5 and $3 \mathrm{~cm}$, which lies exactly in the working area of $A$. alba, where it creates feeding pits (Maire et al. 2007) and deposits faecal pellets (Amouroux et al. 1989), both potentially sustaining bacterial populations (Solan \& Wigham 2005).

\section{Nephtys hombergii: no effect}

Our data indicate no engineering effects of Nephtys hombergii on nematodes. Apart from a lower dominance of species $\left(\mathrm{N}_{\infty}\right.$ in Table 1 , Table $\left.\mathrm{S} 4\right)$, the vertical structure of the nematode community composition was not different from the pattern found in the control sediments. Further, the total nematode density was not affected, which excludes predation of this poly- 
chaete on the nematodes (Tita et al. 2000). Moreover, $N$. hombergii did not alter the environmental variables measured and does not introduce oxygen into the sediment (Braeckman et al. 2010), thereby precluding engineering effects on nematodes via modification of sediment characteristics.

\section{Lanice conchilega: deep sediment oxygenation}

The higher survival of nematodes and the redistribution of several dominant species in the Lanice conchilega treatment suggest that this polychaete has engineering capacities that facilitate nematodes to dwell in deeper layers (Tita et al. 2000, Pinto et al. 2006). In contrast to Abra alba, L. Conchilega did not deplete the chl $a$ and phaeophytin a repository at the surface (and even slightly enhanced chl $a$ and phaeophytin $a$ concentrations at depth when compared to the A. alba treatment) (Fig. 2). In addition, regular and deep oxygen pulses along the tube walls (Forster \& Graf 1995, Braeckman et al. 2010) may be beneficial to nematode survival as well. The recorded high nematode density at depth was mainly visible in Sabatieria celtica and to a lesser extent in Microlaimus conothelis and Richtersia inaequalis profiles. Whereas it is generally accepted that $S$. punctata and $S$. pulchra are resistant (Jensen 1981, 1983, Steyaert et al. 2005) to anoxia and associated elevated hydrogen sulphide concentrations, observations on the distribution of $S$. celtica on the one hand and $M$. conothelis on the other are less clear: Soetaert et al. $(1994,1995)$ showed a deep and opportunistic distribution of $S$. celtica, whereas Jensen (1983) and the control treatment in the present study point to a preference for oxygenated layers. Similarly, Heip et al. (1985), Wetzel et al. (1995) and Steyaert et al. (1999) point towards a deep distribution of $M$. conothelis, whereas the control treatment in the present study showed avoidance of deep layers. Consequently, the presence of the long and slender nematode species $S$. celtica and $M$. conothelis in the deep layers of the $L$. conchilega treatment might be linked to the regular oxygen pulses that reach this depth while at the same time these species can tolerate anaerobic non-irrigated intervals (Reise \& Ax 1979). The presence at depth of the stout species $R$. inaequalis, which is probably vulnerable to oxygen diffusion limitations due to its large body width (Wetzel et al. 1995, Soetaert et al. 2002), further illustrates the $L$. conchilega-induced oxygenation of deeper sediment layers. In addition to the oxygenation of deep sediment layers, deposit-feeding nematodes may profit from the stimulation of bacterial populations in the mucus linings of the tube (Ziegelmeier 1952) or/and in the sediment surrounding the tubes (Solan \& Wigham 2005).

\section{CONCLUSIONS}

The control treatment was detrimental to nematode survival compared to the Lanice conchilega treatment, most probably due to compaction of the sediment, lack of irrigation and associated shallower oxygen penetration depth in the absence of bioturbating macrofauna. In contrast, Abra alba and L. Conchilega showed ecosystem-engineering capacities that extended the possible habitat area to a depth of respectively 3 and $7 \mathrm{~cm}$, probably through removal of sulphide and ammonia and possibly also by stimulation of bacteria as food sources (in faecal pellets and along tube walls, respectively). This indicates again that ecosystemengineering macrobenthos is essential for the survival of lower parts of the food web, such as foraminifera (Bouchet et al. 2009) and nematodes (Van Colen et al. 2009). It is important to note, however, that the outcome of our experiment is likely strongly habitatdependent and the results presented should therefore strictly be interpreted in terms of subtidal fine-sandy habitats under a regular hydrodynamic regime. For instance, muddy sediments are subjected to slow diffusive pore-water transport while advective transport dominates in coarse sediments. Organisms in the first sediment type will therefore benefit from additional macrobenthic engineering of pore water flows, while physical forces may overrule macrobenthic engineering effects in sandy sediments (Olafsson 2003, Meysman et al. 2006). Furthermore, depletion of food resources may be less prevalent in biofilm-covered tidal-flat sediments (Kennedy 1993) or during the seasonal mass input of phytodetritus in subtidal sediments (Franco et al. 2010). Overall, our results reveal that functionally contrasting macrobenthic identities shape nematode communities in different ways. Such different engineering effects may maintain the role of nematodes in ecosystem functioning (Yeates et al. 2009) and the present study therefore highlights the need for the conservation of macrobenthic functional diversity.

Acknowledgements. The crew of RV 'Zeeleeuw' is acknowledged for assistance on board and the conservators of the Flemish Nature Reserve 'Baai van Heist' for entrance permission. We are very grateful to A. Rigaux, A. Van Kenhove and B. Beuselinck for sampling assistance, to A. Van Kenhove for the preparation of hundreds of slides, to D. Van Gansbeke for pigment and water content analysis, to B. Beuselinck for sample grain size processing and to J. Van Tomme for help with the GLM. B. Clarke and M. Andersson are greatly acknowledged for their very instructive interaction at the time of data analysis. We also thank 3 anonymous reviewers for their helpful comments on the manuscript. Support was given to U.B. by the Flemish Fund for Fundamental Research (FWO). This paper contributes to the Westbanks project (www.vliz.be/projects/westbanks), which is supported by the Belgian Science Policy support (BELSPO; contract no. SD/BN/01A) to the Ghent University BBSea Project (GOA 01600705), FWO pro- 
ject (G.0041.08) and the EU Network of Excellence Marbef (GOCE-CT-2003-505446). This is NIOO-KNAW publication number 4906.

\section{LITERATURE CITED}

Aller RC (1988) Benthic fauna and biogeochemical processes in marine sediments: the role of burrow structures. In: Blackburn TH, Sörensen J (eds) Nitrogen cycling in coastal marine environments. Scope, Chichester, p 301-338

Amouroux J, Grémare A, Amouroux J (1989) Modelling of consumption and assimilation in Abra alba (Mollusca, Bivalvia). Mar Ecol Prog Ser 51:87-97

Anderson MJ, Millar RB (2004) Spatial variation and effects of habitat on temperate reef fish assemblages in northeastern New Zealand. J Exp Mar Biol Ecol 305:191-221

Anderson MJ, Robinson J (2003) Generalized discriminant analysis based on distances. Aust NZ J Stat 45:301-318

Anderson MJ, Gorley RN, Clarke KR (2008) PERMANOVA+ for PRIMER: guide to software and statistical methods. PRIMER-E, Plymouth

Austen MC, Thrush SF (2001) Experimental evidence suggesting slow or weak response of nematode community structure to a large suspension-feeder. J Sea Res 46:69-84

Austen MC, Widdicombe S (1998) Experimental evidence of effects of the heart urchin Brissopsis lyrifera on associated subtidal meiobenthic nematode communities. J Exp Mar Biol Ecol 222:219-238

Austen MC, Widdicombe S, Villano-Pitacco N (1998) Effects of biological disturbance on diversity and structure of meiobenthic nematode communities. Mar Ecol Prog Ser 174:233-246

Bouchet VM, Sauriau P, Debenay J, Mermillod-Blondin F, Schmidt S, Amiard J, Dupas B (2009) Influence of the mode of macrofauna-mediated bioturbation on the vertical distribution of living benthic foraminifera: first insight from axial tomodensitometry. J Exp Mar Biol Ecol 371:20-33

Braeckman U, Provoost P, Gribsholt B, Van Gansbeke D and others (2010) Role of macrofauna functional traits and density in biogeochemical fluxes and bioturbation. Mar Ecol Prog Ser 399:173-186

Breslow NE (1984) Extra-Poisson variation in log-linear models. Appl Stat 33:38-44

Clarke K, Gorley RN (2006) Primer v6: user manual/tutorial. PRIMER-E, Plymouth

Dashfield SL, Somerfield PJ, Widdicombe S, Austen MC, Nimmo M (2008) Impacts of ocean acidification and burrowing urchins on within-sediment $\mathrm{pH}$ profiles and subtidal nematode communities. J Exp Mar Biol Ecol 365:46-52

Degraer S, Wittoeck J, Appeltans W, Cooreman K and others (2006) The macrobenthos atlas of the Belgian part of the North Sea. Belgian Science Policy, Brussels

Forster S, Graf G (1995) Impact of irrigation on oxygen flux into the sediment-intermittent pumping by Calianassa subterranea and piston-pumping by Lanice conchilega. Mar Biol 123:335-346

Franco MA, Soetaert K, Van Oevelen D, Van Gansbeke D, Costa MJ, Vincx M, Vanaverbeke J (2008a) Density, vertical distribution and trophic responses of metazoan meiobenthos to phytoplankton deposition in contrasting sediment types. Mar Ecol Prog Ser 358:51-62

Franco M, Steyaert M, Cabral H, Tenreiro R and others (2008b) Impact of discards of beam trawl fishing on the nematode community from the Tagus estuary (Portugal). Mar Pollut Bull 56:1728-1736

Franco M, Vanaverbeke J, Van Oevelen D, Soetaert K, Costa
MJ, Vincx M, Moens T (2010) Respiration partitioning in contrasting subtidal sediments: seasonality and response to a spring phytoplankton deposition. Mar Ecol 31: $276-290$

Gerino M, Stora G, Francois F, Gilbert F and others (2003) Macro-invertebrate functional groups in freshwater and marine sediments: a common mechanistic classification. Vie Milieu 53:221-232

Graf G (1989) Benthic-pelagic coupling in a deep-sea benthic community. Nature 341:437-439

Guisan A, Zimmermann NE (2000) Predictive habitat distribution models in ecology. Ecol Model 135:147-186

Hastings A, Byers JE, Crooks JA, Cuddington K and others (2007) Ecosystem engineering in space and time. Ecol Lett 10:153-164

Heip C, Vincx M, Vranken G (1985) The ecology of marine nematodes. Oceanogr Mar Biol Annu Rev 23:399-489

Hendelberg M, Jensen P (1993) Vertical distribution of the nematode fauna in a coastal sediment influenced by seasonal hypoxia in the bottom water. Ophelia 37:83-94

Jensen P (1981) Species distribution and a microhabitat theory for marine mud dwelling Comesomatidae (Nematoda) in European waters. Cah Biol Mar 22:231-241

Jensen P (1983) Meiofaunal abundance and vertical zonation in a sublittoral soft bottom, with a test of the Haps corer. Mar Biol 74:319-326

Jones CG, Lawton JH, Shachak M (1994) Organisms as ecosystem engineers. Oikos 69:373-386

$>$ Kennedy AD (1993) Minimal predation upon meiofauna by endobenthic macrofauna in the Exe Estuary, south west England. Mar Biol 117:311-319

Kristensen E, Kostka JE (2005) Macrofaunal burrows and irrigation in marine sediment: microbiological and biogeochemical interactions. In: Kristensen E, Haese RR, Kostka JE (eds) Interactions between macro-and microorganisms in marine sediments. American Geophysical Union, Washington, DC, p 125-157

> Levin L, Blair N, DeMaster D, Plaia G, Fornes W, Martin C, Thomas C (1997) Rapid subduction of organic matter by maldanid polychaetes on the North Carolina slope. J Mar Res 55:595-611

Maire O, Duchêne JC, Grémare A, Malyuga VS, Meysman FJR (2007) A comparison of sediment reworking rates by the surface deposit-feeding bivalve Abra ovata during summertime and wintertime, with a comparison between two models of sediment reworking. J Exp Mar Biol Ecol 343:21-36

McIntyre AD (1969) Ecology of marine meiobenthos. Biol Rev Camb Philos Soc 44:245-288

Mermillod-Blondin F, Rosenberg R, Francois-Carcaillet F, Norling K, Mauclaire L (2004) Influence of bioturbation by three benthic infaunal species on microbial communities and biogeochemical processes in marine sediment. Aquat Microb Ecol 36:271-284

Meysman FJ, Middelburg JJ, Heip CH (2006) Bioturbation: a fresh look at Darwin's last idea. Trends Ecol Evol 21: 688-695

Michaud E, Desrosiers G, Mermillod-Blondin F, Sundby B, Stora G (2006) The functional group approach to bioturbation: II. The effects of the Macoma balthica community on fluxes of nutrients and dissolved organic carbon across the sediment-water interface. J Exp Mar Biol Ecol 337:178-189

Olafsson E (2003) Do macrofauna structure meiofauna assemblages in marine soft-bottoms? A review of experimental studies. Vie Milieu 53:249-265

Olafsson E, Elmgren R, Papakosta O (1993) Effects of the deposit-feeding benthic bivalve Macoma balthica on meiobenthos. Oecologia 93:457-462 
Pinto TK, Austen MC, Bemvenuti CE (2006) Effects of macroinfauna sediment disturbance on nematode vertical distribution. J Mar Biol Assoc UK 86:227-233

Platt HM (1977) Vertical and horizontal distribution of freeliving marine nematodes from Strangford Lough, Northern Ireland. Cah Biol Mar 18:261-273

Rabaut M (2009) Lanice conchilega, fisheries and marine conservation: towards an ecosystem approach to marine management. PhD thesis, Ghent University

Reichman OJ, Seabloom EW (2002) The role of pocket gophers as subterranean ecosystem engineers. Trends Ecol Evol 17:44-49

Reise K (1983) Biotic enrichment of intertidal sediments by experimental aggregates of the deposit-feeding bivalve Macoma balthica. Mar Ecol Prog Ser 12:229-236

Reise K (1985) Macrofauna promotes meiofauna. Tidal flat ecology. An experimental approach to species interactions. In: Billings WD, Golley F, Lange OL, Olson JS, Remmert H (eds) Ecological studies: analysis and synthesis, Vol 54. Springer-Verlag, Berlin, p 119-145

Reise K, Ax P (1979) A meiofaunal 'thiobios' limited to the anaerobic sulfide system of marine sand does not exist. Mar Biol 54:225-237

Schratzberger M, Warwick R (1999) Impact of predation and sediment disturbance by Carcinus maenas (L.) on freeliving nematode community structure. J Exp Mar Biol Ecol 235:255-271

Soetaert K, Vincx M, Wittoeck J, Tulkens M, Van Gansbeke D (1994) Spatial patterns of Westerschelde meiobenthos. Estuar Coast Shelf Sci 39:367-388

Soetaert K, Vincx M, Wittoeck J, Tulkens M (1995) Meiobenthic distribution and nematode community structure in five European estuaries. Hydrobiologia 311:185-206

Soetaert K, Muthumbi A, Heip C (2002) Size and shape of ocean margin nematodes: morphological diversity and depth-related patterns. Mar Ecol Prog Ser 242:179-193

Solan M, Wigham BD (2005) Biogenic particle reworking and bacterial-invertebrate interactions in marine sediments. In: Kristensen E, Kostka JE, Haese RR (eds) Interactions between macro- and microorganisms in marine sediments. American Geophysical Union, Washington, DC, p 105-124

Steyaert M, Garner N, van Gansbeke D, Vincx M (1999) Nematode communities from the North Sea: environmental controls on species diversity and vertical distribution within the sediment. J Mar Biol Assoc UK 79:253-264

Steyaert M, Vanaverbeke J, Vanreusel A, Barranguet C, Lucas C, Vincx M (2003) The importance of fine-scale, vertical profiles in characterising nematode community structure. Estuar Coast Shelf Sci 58:353-366

Steyaert M, Moodley L, Vanaverbeke J, Vandewiele S, Vincx M, Meire P, Van Damme S (2005) Laboratory experiments

Editorial responsibility: Hans Heinrich Janssen,

Oldendorf/Luhe, Germany on the infaunal activity of intertidal nematodes. Hydrobiologia 540:217-223

Steyaert M, Moodley L, Nadong T, Moens T, Soetaert K, Vincx M (2007) Responses of intertidal nematodes to short-term anoxic events. J Exp Mar Biol Ecol 345:175-184

Tita G, Desrosiers G, Vincx M, Nozais C (2000) Predation and sediment disturbance effects of the intertidal polychaete Nereis virens (Sars) on associated meiofaunal assemblages. J Exp Mar Biol Ecol 243:261-282

Van Colen C, Montserrat F, Verbist K, Vincx M and others (2009) Tidal flat nematode responses to hypoxia and subsequent macrofauna-mediated alterations of sediment properties. Mar Ecol Prog Ser 372:31-42

Van Hoey G, Degraer S, Vincx M (2004) Macrobenthic community structure of soft-bottom sediments at the Belgian Continental Shelf. Estuar Coast Shelf Sci 59:599-613

Warwick RM, Platt HM, Somerfield PJ (1998) Free-living marine nematodes. Part III. British monhysterids. Synopses of the British Fauna (New Series) 53. Field Studies Council, Shrewsbury

Wetzel MA, Jensen P, Giere O (1995) Oxygen/sulfide regime and nematode fauna associated with Arenicola marina burrows: new insights in the thiobios case. Mar Biol 124: 301-312

Widdicombe S, Kendall MA, Parry DM (2003) Using the surface-features created by bioturbating organisms as surrogates for macrofaunal diversity and community structure. Vie Milieu 53:179-186

Wieser W (1953) Die Beziehung zwischen Mundhöhlengestalt, Ernährungsweise und Vorkommen bei freilebenden marinen Nematoden. Eine Ökologisch-morphologische Studie. Ark Zool 4:439-483

Wright SW, Jeffrey SW (1997) High-resolution HPLC system for chlorophylls and carotenoids of marine phytoplankton. In: Jeffrey SW, Mantoura RFC, Wright SW (eds) Phytoplankton pigments in oceanography: guidelines to modern methods. UNESCO, Paris, p 327-341

Yeates GW, Ferris H, Moens T (2009) The role of nematodes in ecosystems. In: Wilson MJ, Kakouli-Duarte $\mathrm{T}$ (eds) Nematodes as environmental indicators. CABI, Wallingford, p 1-44

Ziegelmeier E (1952) Beobachtungen über den Röhrenbau von Lanice conchilega (Pallas) im Experiment und am natürlichen Standort. Helgol Meeresunters 4:107-129

Ziegelmeier E (1969) Neue Untersuchungen über die Wohnröhren-Bauweise von Lanice conchilega (Polychaeta, Sedentaria). Helgol Mar Res 19:216-229

Zühlke R, Blome D, van Bernem KH, Dittmann S (1998) Effects of the tube-building polychaete Lanice conchilega (Pallas) on benthic macrofauna and nematodes in an intertidal sandflat. Senckenb Marit 29:131-138

Submitted: June 3, 2010; Accepted: November 1, 2010

Proofs received from author(s): January 11, 2011 